\title{
Phytochemical profile and antimicrobial properties of volatile compounds of Satureja calamintha (L) Scheel from northern Algeria
}

\author{
Khaled Boudjema ${ }^{1,2 \star}$, Amel Bouanane ${ }^{2}$, Souad Gamgani ${ }^{2}$, Mourad Djeziri ${ }^{1,3}$, \\ Mohamed Abou Mustapha ${ }^{3}$, Fathia Fazouane ${ }^{1,2}$ \\ ${ }^{1}$ Research Laboratory in Food Technology, ${ }^{2}$ Laboratory of Applied Biochemistry, Department of Biology, University of \\ M'Hamed, Bougara, Boumerdes, 35000, ${ }^{3}$ Research Centre in Physicochemical Analysis, Bousmail, 42000, Algeria
}

*For correspondence: Email: boudjemasidi@yahoo.fr; Tel: +213552553941

Sent for review: 4 January 2018

Revised accepted: 22 April 2018

\begin{abstract}
Purpose: To undertake the phytochemical screening of Satureja calamintha (L.) Scheel., and evaluate the antimicrobial activities of its volatile compounds.

Methods: Qualitative phytochemical analysis of the plant was performed using standard methods. The extraction of essential oils (EOs) was conducted using steam distillation, while the chemical composition was determined using gas chromatography-mass spectrometry (GC-MS). The antimicrobial activities of the oils were evaluated against ten bacterial and six fungal strains using disc-diffusion assay and poisoned food technique, respectively.

Results: After steam distillation, the extraction yield was $0.54 \pm 0.11 \%$. GC-MS analysis identified approximately $99.99 \%$ of the EOs. The three most abundant compounds identified were l-menthone $(32.10 \%)$, neo-menthol $(32.07 \%)$ and pulegone $(22.35 \%)$. The oils had significant $(p<0.05)$ antimicrobial activities against the tested bacterial and fungal strains, except Bacillus cereus and Candida albicans. The lowest minimum inhibitory concentration (MIC) for bacteria was $0.007 \%(\mathrm{~V} / \mathrm{V})$ against Enterococcus faecalis and Klebsiella pneumoniae, whereas for fungi, it was $0.500 \%$ (V/V) against Candida albicans. Moreover, Enterococcus faecalis and Listeria innocua had the lowest minimum bactericidal concentration $(M B C)$ at $0.125 \%(\mathrm{~V} / \mathrm{V})$, in contrast to the lowest fungicidal concentration (MFC) for Candida albicans at $0.500 \%(\mathrm{~V} / \mathrm{V})$.

Conclusion: These results demonstrate that EOs from Satureja calamintha (L.) Scheel. possess significant antimicrobial activities which might be useful for therapeutic and pharmaceutical applications.
\end{abstract}

Keywords: Satureja calamintha, Phytochemicals, Essential oils, Antimicrobial activity, Steam distillation

This is an Open Access article that uses a funding model which does not charge readers or their institutions for access and distributed under the terms of the Creative Commons Attribution License (http://creativecommons.org/licenses/by/4.0) and the Budapest Open Access Initiative (http://www.budapestopenaccessinitiative.org/read), which permit unrestricted use, distribution, and reproduction in any medium, provided the original work is properly credited.

Tropical Journal of Pharmaceutical Research is indexed by Science Citation Index (SciSearch), Scopus, International Pharmaceutical Abstract, Chemical Abstracts, Embase, Index Copernicus, EBSCO, African Index Medicus, JournalSeek, Journal Citation Reports/Science Edition, Directory of Open Access Journals (DOAJ), African Journal Online, Bioline International, Open-J-Gate and Pharmacy Abstracts

\section{INTRODUCTION}

Fungal infections have become increasingly recognized as important threats in critically-ill patients. They are characterized by easy transmission, wide prevalence and a large variety of human and animal reservoirs [1]. Reports on food-borne diseases caused by the consumption of food contaminated with pathogenic bacteria are increasing worldwide [2]. 
Each year, an estimated $30 \%$ of people in industrialized nations suffer from these diseases [3].

Synthetic antimicrobial substances are undeniably one of the most important therapeutic discoveries of the $20^{\text {th }}$ century; they are effective against serious bacterial and fungal infections. However, most of these pathogenic microorganisms have developed new resistance to several antibiotics. There has been renewed interest in plants and their natural antimicrobial agents as alternatives for reducing the problem of resistance [4]. Among these, essential oils (EOs) have received special attention as natural agents with great potential for food preservation and other pharmacological effects such as antispasmodial, carminative, hepatoprotective, antiviral and anti-cancer activities [5].

Algeria is well-known for its biodiversity, with about three hundred species of plants, $15 \%$ of which are endemic and belong to several botanical families.

The aim of this study was to perform phytochemical screening on the aerial parts of Satureja calamintha (L.), and to evaluate the antimicrobial activities of its essential oils.

\section{EXPERIMENTAL}

\section{Plant material}

Aerial parts of Satureja calamintha (L.) Scheel. were collected from the Jijel region of Algeria (Eastern Algeria) and identified by Prof C. Baali of the Department of Botany, Higher National Agronomic School, Algeria. A specimen of the plant was prepared and deposited in the ENSA Herbarium. The aerial parts of the plant were washed and shade-dried in a well-ventilated room.

\section{Phytochemical screening}

The qualitative screening for tannins, saponosides, glycosides, alkaloids, quinones, reducing sugars, coumarins and flavonoids were carried out using standard methods [6].

\section{Extraction of essential oils}

Extraction of essential oils (EOs) from the aerial parts of the plant were extracted using steam distillation. A weighed portion $(100 \mathrm{~g})$ of dried aerial parts was suspended in $300 \mathrm{~mL}$ of distilled water with intermittent stirring for $3 \mathrm{~h}$. The oils obtained after extraction were dried over anhydrous sodium sulfate $\left(\mathrm{Na}_{2} \mathrm{SO}_{4}\right)$ and kept in the refrigerator at $4{ }^{\circ} \mathrm{C}$ in sealed opaque bottles.

\section{Test microorganisms}

Ten bacterial and six fungal strains were purchased from the American-Type Culture Collection (ATCC), and were used for testing the antimicrobial activities of the EOs. The strains were Bacillus cereus ATCC 10876, Enterococcus faecalis ATCC 49452, Listeria innocua CLIP 74915, methicillin-resistant Staphylococcus aureus (MRSA) ATCC 43300, Staphylococcus aureus ATCC 25923, Escherichia coli ATCC 25922, Klebsiella pneumoniae ATCC 700603, Salmonella enterica ATCC 43972, Salmonella typhimurium ATCC 13311, Pseudomonas aeruginosa ATCC 853, Candida tropicalis DIV13Z087D0VS, Candida tropicalis DIV13-Z087B0VS [7], Candida albicans ATCC 1024, Aspergillus niger 1, Aspergillus niger 2 and Aspergillus flavus.

\section{Analysis of essential oils by GC-MS}

The identification and quantification of essential oils present in the aerial parts of the plant were carried out using HP 6890 gas chromatography coupled to an HP5973 mass spectrometer. Sample volume of $0.2 \mu \mathrm{L}$ was injected in split mode (split ratio of $50: 1$ ) into a column capillary HP-5MS (30 m x $0.25 \mathrm{~mm} \times 0.25 \mu \mathrm{m})$, containing a mixture of phenyl polysiloxane $(5 \%)$ and methyl polysiloxane (95\%). The separation was carried out using helium as the carrier gas at a flow rate of $0.5 \mathrm{ml} / \mathrm{min}$ under the following conditions: First, the oven temperature was set at $60{ }^{\circ} \mathrm{C}$ for $8 \mathrm{~min}$, increased further to $250^{\circ} \mathrm{C}$ at a rate of $2{ }^{\circ} \mathrm{C} / \mathrm{min}$, and finally maintained at $250{ }^{\circ} \mathrm{C}$ for $10 \mathrm{~min}$. The injection and detector temperatures were maintained at 250 and 230 ${ }^{\circ} \mathrm{C}$, respectively. Individual components were identified by comparing their mass spectra with those of standards, and also by comparing their GC-retention indices with those recorded in literature. The components of the EOs were expressed as percentages determined by integration of GC peak areas without using correction factors.

\section{Evaluation of antibiotic sensitivity and antibacterial activities}

The pathogenic bacterial strains were tested for their sensitivities against a range of antibiotics: ampicillin (Amp30), chloramphenicol (C30), cefotaxime (Ct30), gentamycin (Gen10), vancomycin (Va30), cefoperazone (Cep30) and tetracycline (Te30), using the Kirby-Bauer method [8]. The antibacterial activities of the EOs 
were determined using disc-diffusion assay. A single colony from an overnight bacterial culture plate was transferred into tubes containing $5 \mathrm{~mL}$ of sterile saline solution to obtain the bacterial suspension. This was adjusted to $0.5 \mathrm{McF}$ arland standard, approximately corresponding to an initial inoculum size of $10^{8}$ colony-forming units per milliliter $(\mathrm{CFU} / \mathrm{mL})$. The bacterial suspension was diluted $1: 100$ to obtain $10^{6} \mathrm{CFU} / \mathrm{mL}$.

Using a sterile swab, $200 \mu \mathrm{L}$ of fresh culture was spread on Muller Hinton agar plates, and $20 \mu \mathrm{L}$ of EO was dispensed on the sterile paper disc 6 $\mathrm{mm}$ in diameter. The EO disc and antibioticcontaining discs were deposited separately on the surface of each inoculated agar plate and incubated at $37^{\circ} \mathrm{C}$ for $24 \mathrm{~h}$. Chloramphenicol (15 $\mu \mathrm{g} / \mathrm{disc}$ ) was used as a positive control. The antibacterial activity was estimated by measuring the diameter of the inhibition zone surrounding each disc.

\section{Evaluation of antifungal activity}

The antifungal activity was evaluated using the disc-diffusion method for yeast, while poisoned food technique was used for mold [9]. In the discdiffusion method, a colony from a two-day yeast culture plate was transferred to tubes containing $5 \mathrm{~mL}$ of sterile saline solution to obtain a yeast suspension corresponding approximately to an initial inoculum size of $10^{4} \mathrm{CFU} / \mathrm{mL}$. A portion of the fresh culture $(200 \mu \mathrm{L})$ was inoculated on Sabouraud Dextrose agar plates. This was followed by the injection of $20 \mu \mathrm{L}$ of EOs on a sterile paper disc $6 \mathrm{~mm}$ in diameter, which was further deposited on the surface of each inoculated agar plate and incubated at $25^{\circ} \mathrm{C}$ for $48 \mathrm{~h}$. Griseofulvin $(15 \mu \mathrm{g} / \mathrm{disc})$ was used as a positive control and the antifungal activity was estimated by measuring the diameter of the inhibition zone surrounding each disc.

In the poisoned food technique, $30 \mu \mathrm{L}$ of EOs and two drops of Tween 80 were transferred to a sterile tube containing $13.5 \mathrm{~mL}$ of molten Sabouraud Dextrose agar medium and cooled at $45{ }^{\circ} \mathrm{C}$. The mixture obtained was shaken manually and dispensed on sterile petri dishes. After solidification of the medium, a mycelial disc measuring approximately $6 \mathrm{~mm}$ in diameter, cut from a fungal culture of 5 days, was deposited in the center of each petri plate, and further incubated at $25^{\circ} \mathrm{C}$. Control plates without EOs, were treated following the same procedure with nystatin $(30 \mu \mathrm{L})$ as the positive control. The diameter of mycelial growth was recorded after five days of incubation and the percentage inhibition of mycelial growth (M) was calculated as in Eq 1.
$M(\%)=\left\{1-\left(D_{E O S} / D c\right)\right\} 100$

where $D c$ is the mean diameter of mycelial growth in the control sample, and $D_{E O S}$ is the mean diameter of mycelial growth treated with EOs.

\section{Determination of minimum inhibitory concentrations (MIC)}

The MICs of the EOs were determined using the micro-dilution method [10]. Stock solutions of EOs were prepared at concentration of $1.000 \%$ ( $v / v)$ and diluted in Muller Hinton broth and Sabouraud Dextrose broth to obtain concentrations in the range of 0.007 to $1.000 \%$ $(w / v)$. Portions of each concentration $(100 \mu \mathrm{L})$ were transferred to wells and inoculated separately with $10 \mu \mathrm{L}$ of the microbial suspensions $\left(10^{6} \mathrm{CFU} / \mathrm{mL}\right.$ for bacteria and $10^{4}$ $\mathrm{CFU} / \mathrm{mL}$ for fungi). The incubation temperatures for bacteria and fungi were $37^{\circ} \mathrm{C}$ and $25^{\circ} \mathrm{C}$, respectively. Chloramphenicol, nystatin and griseofulvin were used as positive controls. The MIC was defined as the lowest concentration of EOs that resulted in no visible growth of microorganisms.

\section{Evaluation of minimum bactericidal concentration (MBC) and minimum fungicidal concentration (MFC)}

After MIC determination, the wells that showed no visible growth of microorganisms were used for determination of MBC for bacteria, and MFC for fungi. Different concentrations of EOs ranging from 0.007 to $1.000 \%(\mathrm{w} / \mathrm{v})$ were prepared in Muller Hinton broth and Sabouraud Dextrose broth. Portions of each concentration $(100 \mu \mathrm{L})$ were transferred to the wells and were inoculated separately with $10 \mu \mathrm{L}$ of the microbial suspensions $\left(10^{6} \mathrm{CFU} / \mathrm{mL}\right.$ for bacteria and $10^{4}$ $\mathrm{CFU} / \mathrm{mL}$ for fungi), at $37{ }^{\circ} \mathrm{C}$ for bacteria, and at $25{ }^{\circ} \mathrm{C}$ for fungi. Chloramphenicol, nystatin and griseofulvin were used as positive controls. The MBC and MFC were defined as the lowest concentrations of EOs that completely killed the initial inoculums of bacteria and fungi, respectively.

\section{Statistical analysis}

Statistical analyses were performed with Microsoft Excel 2010 and the results are presented as mean \pm standard deviation (SD) of three replicates. All the data were statistically evaluated using Student's $t$-test and significant difference between the means was set at $p<$ 0.05 . 


\section{RESULTS}

\section{Phytochemical profile}

From Table 1, twelve groups of chemical compounds were detected, namely flavonoids, anthocyanins, total and gallic tannins, glycosides, saponosides, reducing compounds, holosides, alkaloids, coumarins, O-heterosides and Cglycosides. Leucoanthocyanins and quinones were not detected, whereas catechic tannins and saponosides were present in minimal amounts.

Table 1: Phytochemical profile of aerial parts of Satureja calamintha

\begin{tabular}{|c|c|}
\hline Phytochemical & Result \\
\hline Flavonoids & +++ \\
\hline Anthocyanins & ++ \\
\hline Leucoanthocyanins & - \\
\hline Total tannins & +++ \\
\hline Catechic tannins & + \\
\hline Gallic tannins & +++ \\
\hline Glycosides & ++ \\
\hline Saponosides & + \\
\hline Quinones & - \\
\hline Reducing compounds & +++ \\
\hline Oses and holosides & + \\
\hline Alkaloids & +++ \\
\hline Coumarins & +++ \\
\hline O-heterosides & +++ \\
\hline C-heterosides & +++ \\
\hline $\begin{array}{l}(-) \text { : Absent, (+): Pres } \\
\text { Present in medium } \\
\text { appreciable quantity }\end{array}$ & $\begin{array}{l}\text { in minir } \\
\text { antity, }\end{array}$ \\
\hline
\end{tabular}

The extracted volatile substances had aromatic odor and yellow color. The average yield of EOs was about $0.54 \pm 0.11 \%$. The aerial parts of the plant contained three major compounds: Imenthone (32.10\%), neo-menthol (32.07\%) and pulegone $(22.35 \%)$.

\section{Antibacterial and antifungal activities}

The bacterial strains reacted differently to the tested antibiotics; with inhibition zones varying from 6 to $45 \mathrm{~mm}$. Enterococcus faecalis seemed resistant to Gen10 (12 mm) and susceptible to the other antibiotics, whereas MRSA appeared resistant to Te30 and Va30 $(6 \mathrm{~mm})$. Cep30 had a larger spectrum of inhibition than Gen10, Te30 and Va30. It exhibited a smaller inhibition zone, varying from 6 to $10.5 \mathrm{~mm}$. Amp30 and Ct30 seemed to be the most efficient antibiotics against all the tested bacterial strains (6 - 15 $\mathrm{mm})$, whereas C30 appeared to be the most effective with an inhibition zone varying from 25 to $39 \mathrm{~mm}$.

Table 2: Extraction yield and compositional analysis of volatile fractions of Satureja calamintha.

\begin{tabular}{|c|c|c|c|}
\hline No. & Constituent & $\begin{array}{l}\text { Retention } \\
\text { time (min) }\end{array}$ & $\begin{array}{c}\text { Content } \\
(\%)\end{array}$ \\
\hline 1 & Alpha.-Thujene & 10.28 & 0.01 \\
\hline 2 & Alpha.-Pinene & 10.68 & 0.45 \\
\hline 3 & Camphene & 11.55 & 0.04 \\
\hline 4 & Sabinene & 13.13 & 0.28 \\
\hline 5 & Beta.-Pinene & 13.32 & 0.57 \\
\hline 6 & Beta.-Myrcene & 14.33 & 0.30 \\
\hline 7 & 3-Octanol & 14.69 & 0.16 \\
\hline 8 & Pseudolimonene & 15.12 & 0.02 \\
\hline 9 & Alpha.-Terpinene & 16.00 & 0.01 \\
\hline 10 & Benzene & 16.59 & 0.01 \\
\hline 11 & 1,8-Cineole & 17.08 & 3.33 \\
\hline 12 & Beta.-Ocimene & 18.31 & 0.01 \\
\hline 13 & Gamma.-Terpinene & 18.99 & 0.03 \\
\hline 14 & 4-Thujanol & 19.64 & 0.03 \\
\hline 15 & Alpha.-Terpinolene & 21.10 & 0.04 \\
\hline 16 & L-Linalool & 22.22 & 0.07 \\
\hline 17 & Camphor & 25.14 & 0.03 \\
\hline 18 & I-Menthone & 26.56 & 32.10 \\
\hline 19 & neo-Menthol & 27.59 & 32.07 \\
\hline 20 & Menthol & 27.75 & 0.13 \\
\hline 21 & Isopulegone & 27.91 & 0.57 \\
\hline 22 & Menthol & 28.30 & 0.25 \\
\hline 23 & 2-Carene & 28.84 & 0.11 \\
\hline 24 & Cumene & 31.33 & 0.03 \\
\hline 25 & Pulegone & 32.59 & 22.35 \\
\hline 26 & Piperitone Oxide & 33.41 & 3.31 \\
\hline 27 & Seudenone & 34.29 & 0.04 \\
\hline 28 & Thymol & 36.02 & 0.06 \\
\hline 29 & Diosphenol & 36.14 & 0.07 \\
\hline 30 & Cyclohexane & 36.39 & 0.02 \\
\hline 31 & Artemisia triene & 38.56 & 0.01 \\
\hline 32 & Pulespenone & 38.84 & 0.24 \\
\hline 33 & Eugenol & 40.04 & 0.04 \\
\hline 34 & Piperitenone Oxide & 40.57 & 0.32 \\
\hline 35 & Copaene & 41.06 & 0.03 \\
\hline 36 & Beta. Bourbonene & 41.64 & 0.02 \\
\hline 37 & Beta.-Elemene & 42.15 & 0.04 \\
\hline 38 & Cinerolon & 42.70 & 0.03 \\
\hline 39 & Alpha.-Gurjunene & 43.20 & 0.01 \\
\hline 40 & Caryophyllene & 43.81 & 0.15 \\
\hline 41 & Geranylacetone & 46.06 & 0.03 \\
\hline 42 & Beta.-Farnesene & 46.30 & 0.10 \\
\hline 43 & Beta.-Cubebene & 47.73 & 1.46 \\
\hline 44 & Bicyclogermacrene & 48.63 & 0.62 \\
\hline 45 & Delta-Cadinene & 50.24 & 0.02 \\
\hline 46 & Palustrol & 52.81 & 0.05 \\
\hline 47 & (+) Spathulenol & 53.43 & 0.05 \\
\hline 48 & d-Ledol & 54.86 & 0.02 \\
\hline 49 & Isobicyclogermacrene & 57.81 & 0.01 \\
\hline
\end{tabular}

The results of antibacterial activity are presented in Table 4. The essential oils had significant antibacterial effects against all tested bacteria, with inhibition diameters between 10.33 and 30 $\mathrm{mm}$, except for Salmonella enterica, which had low sensitivity $(7.33 \pm 2.62 \mathrm{~mm})$. 
Table 3: Selected antibiotics and their antimicrobial activities

\begin{tabular}{|c|c|c|c|c|c|c|c|}
\hline \multirow[t]{2}{*}{ Test strain } & \multicolumn{7}{|c|}{ Antibiotics } \\
\hline & Gen10 & C30 & Te30 & Va30 & Amp30 & Ct30 & Cep30 \\
\hline \multicolumn{8}{|l|}{ Gram-positive bacteria } \\
\hline Bacillus cereus ATCC 10876 & $27.5 \pm 0.5$ & $25 \pm 0.0$ & $16.5 \pm 0.5$ & $19.5 \pm 0.5$ & $6 \pm 0.0$ & $6 \pm 0.0$ & $6 \pm 0.0$ \\
\hline Enterococcus faecalis ATCC 49452 & $12 \pm 0.0$ & $30 \pm 0.0$ & $30 \pm 0.0$ & $22 \pm 0.0$ & $6 \pm 0.0$ & $7 \pm 0.0$ & $6 \pm 0.0$ \\
\hline Listeria innucua CLIP 74915 & $32 \pm 0.0$ & $33.5 \pm 0.5$ & $19.5 \pm 1.5$ & $27 \pm 10$ & $14.5 \pm 0.5$ & $6 \pm 0.0$ & $40 \pm 0.0$ \\
\hline RMSA ATCC 43300 & $28 \pm 0.0$ & $27.5 \pm 0.5$ & $6 \pm 0.0$ & $6 \pm 0.0$ & $8 \pm 0.0$ & $6 \pm 0.0$ & $10.5 \pm 0.5$ \\
\hline $\begin{array}{l}\text { Staphylococcus aureus ATCC } 25923 \\
\text { Gram-negative bacteria }\end{array}$ & $32.5 \pm 0.5$ & $33 \pm 0.0$ & $21 \pm 1$ & $25.5 \pm 0.5$ & $8.5 \pm 0.5$ & $7 \pm 0.0$ & $37.5 \pm 0.5$ \\
\hline Escherichia coli ATCC 25922 & $37.5 \pm 2.5$ & $45 \pm 0.0$ & $35 \pm 0.0$ & $8.5 \pm 0.5$ & $6 \pm 0.0$ & $9.5 \pm 0.5$ & $30 \pm 0.0$ \\
\hline Klebseila pneumoniae ATCC 700603 & $17.5 \pm 0.5$ & $31 \pm 0.0$ & $38.5 \pm 1.5$ & $25.5 \pm 0.5$ & $6 \pm 0.0$ & $7 \pm 0.0$ & $6 \pm 0.0$ \\
\hline $\begin{array}{l}\text { Salmonella enterica ATCC } 43972 \\
\text { Salmonella typhimurium ATCC } 13311\end{array}$ & $17.5 \pm 0.5$ & $35.5 \pm 0.5$ & $\begin{array}{c}32.5 \pm 0.5 \\
30 \pm 0.0\end{array}$ & $23.5 \pm 0.5$ & $\begin{array}{c}6 \pm 0.0 \\
15 \pm 0.0\end{array}$ & $9.5 \pm 0.5$ & $30 \pm 0.0$ \\
\hline Pseudomonas aerogenosa ATCC 853 & $34.5 \pm 0.5$ & $39 \pm 0.0$ & $22 \pm 10$ & $26.5 \pm 0.5$ & $13.5 \pm 0.5$ & $6.5 \pm 0.5$ & $39 \pm 10$ \\
\hline
\end{tabular}

Data are inhibition diameters $(\mathrm{mm})$ of selected antibiotics

The antibacterial activities of the oils were significantly higher $(p<0.05)$ against Enterococcus faecalis, Listeria innocua, Staphylococcus aureus, Escherichia coli, Klebseila pneumoniae, Salmonella enterica and Pseudomonas aeroginosa, when compared to the effects of choloramphenicol.

The oils had moderate antifungal activities, ranging from 10.66 to $39.66 \mathrm{~mm}$. All results were statistically significant $(p<0.05)$, with the exception of Candida tropicalis DIV13Z087D0VS. The fungal strains reacted differently to the oils, with variable percentages of inhibition between 54.44 and $71.25 \%$.

\section{MIC, MBC and MFC}

The minimum inhibitory concentration (MIC), minimum bactericidal concentration (MBC) and minimum fungicidal concentration (MFC) of EOs against all tested strains are shown in Table 5. The MIC ranged from 0.007 to $1.000 \%$ (v/v) for bacteria and from 0.250 to $1.000 \%(\mathrm{v} / \mathrm{v})$ for fungi. The lowest MIC for the EOs in the case of bacteria was observed with Enterococcus faecalis and Klebsiella pneumoniae corresponding to $0.007 \%(\mathrm{v} / \mathrm{v})$, whereas it was $0.500 \%(\mathrm{v} / \mathrm{v})$ for Candida albicans in case of fungi. Two bacterial stains (i.e. Enterococcus faecalis and Listeria innocua), showed a bactericidal effect with a low MCB of $0.125 \%$ (v/v), whereas Candida albicans was considered a sensitive fungal strain with an MFC of $0.500 \%$ $(\mathrm{v} / \mathrm{v})$.

Table 4: Antibacterial and antifungal activities of EOs from Satureja calamintha and standard antibiotics

\begin{tabular}{|c|c|c|c|c|}
\hline Test strain & $\begin{array}{l}\mathrm{ZI}(\mathrm{mm}) \\
\text { essential oils }\end{array}$ & $\begin{array}{l}\mathrm{Zl}(\mathrm{mm}) \\
\text { Chloramphenicol }\end{array}$ & $\begin{array}{l}\text { Zl(mm) } \\
\text { Griseofulvin }\end{array}$ & $\begin{array}{l}\mathrm{PI}(\%) \\
\text { Nystatin }\end{array}$ \\
\hline \multicolumn{5}{|l|}{ Gram-positive bacteria } \\
\hline Bacillus cereus ATCC 10876 & $24 \pm 1.41$ & $25 \pm 0.0$ & - & - \\
\hline Enterococcus faecalis ATCC 49452 & $18.33 \pm 20^{* \pi}$ & $30 \pm 0.0$ & - & - \\
\hline Listeria innucua CLIP 74915 & $10.33 \pm 1.24$ & $33.5 \pm 0.5$ & - & - \\
\hline MRSA ATCC 43300 & $30 \pm 1.63$ & $27.5 \pm 0.5$ & - & - \\
\hline Staphylococcus aureus ATCC 25923 & $13.66 \pm 20$ & $33 \pm 0.0$ & - & - \\
\hline Gram-negative bacteria & & & - & - \\
\hline Escherichia coli ATCC 25922 & $12 \pm 1.63^{\pi \times \pi}$ & $43.66 \pm 1.33$ & - & - \\
\hline Klebseila pneumoniae ATCC 700603 & $11 \pm 0.81^{\pi \times \pi}$ & $31 \pm 0.0$ & - & - \\
\hline Salmonella enterica ATCC 43972 & $7.33 \pm 2.62$ & $35.5 \pm 0.5$ & - & - \\
\hline Salmonella typhimurium ATCC 13311 & $22 \pm 1.63$ & $24.5 \pm 1.5$ & - & - \\
\hline \multicolumn{4}{|l|}{ Yeast } & - \\
\hline Candida albicans ATCC 1024 & $20 \pm 0.0^{\approx \pi}$ & - & $26.5 \pm 0.5$ & - \\
\hline Candida tropicalis DIV13-Z087D0VS & $10.66 \pm 1.69$ & - & $8.33 \pm 0.47$ & - \\
\hline Candida tropicalis DIV13-Z087B0VS & $39.33 \pm 4.71$ & - & $7.66 \pm 0.94$ & - \\
\hline Mold & $\begin{array}{c}\text { PI (\%) } \\
\text { Essential oils }\end{array}$ & & & \\
\hline Aspergillus niger 1 & 54.44 & - & - & 3.33 \\
\hline Aspergillus niger 2 & 48.88 & - & - & 28.88 \\
\hline Aspergillus flavus & 71.25 & - & - & 17.5 \\
\hline
\end{tabular}

Zl: zone of inhibition, PI: \% inhibition, -: not determined 
Table 5: Minimum inhibitory concentrations of EOs on test microorganisms

\begin{tabular}{|c|c|c|c|c|}
\hline \multirow[t]{2}{*}{ Test strain } & \multicolumn{2}{|c|}{ Essential oils } & \multicolumn{2}{|c|}{$\begin{array}{c}\text { Standard } \\
\text { (Chloramphenicol) }\end{array}$} \\
\hline & $M I C(\% \mathrm{v} / \mathrm{v})$ & $\begin{array}{c}M B C \text { or } M F C \\
(\% \mathrm{v} / \mathrm{v})\end{array}$ & $\begin{array}{c}M I C(\% \\
v / v)\end{array}$ & $\begin{array}{c}M B C \text { or } \\
M F C(\% \text { v/v) }\end{array}$ \\
\hline \multicolumn{5}{|l|}{ Gram-positive bacteria } \\
\hline Bacillus cereus ATCC 10876 & $>1.000$ & - & 0.250 & 1.000 \\
\hline Enterococcus faecalis ATCC 49452 & $<0.007$ & 0.125 & 0.250 & 0.500 \\
\hline Listeria innucua CLIP 74915 & 0.062 & 0.125 & 0.250 & $>1.000$ \\
\hline MRSA ATCC 43300 & 1.000 & 1.000 & 1.000 & $>1.000$ \\
\hline Staphylococcus aureus ATCC 25923 & 0.125 & 1.000 & 0.500 & $>1.000$ \\
\hline \multicolumn{5}{|l|}{ Gram-negative bacteria } \\
\hline Escherichia coli ATCC 25922 & $>1.000$ & - & 0.500 & $>1.000$ \\
\hline Klebseila pneumoniae ATCC 700603 & $<0.007$ & - & 0.250 & $>1.000$ \\
\hline Salmonella enterica ATCC 43972 & 0.015 & 1.000 & 0.500 & 0.500 \\
\hline Salmonella typhimurium ATCC 13311 & $>1.000$ & - & 0.500 & $>1.000$ \\
\hline Pseudomonas aerogenosa ATCC 853 & 0.500 & 1.000 & 0.250 & 1.000 \\
\hline \multicolumn{5}{|l|}{ Fungi } \\
\hline Yeast & & & Nystatin & \\
\hline Candida albicans ATCC 1024 & 0.500 & 0.500 & 1.000 & 1.000 \\
\hline Candida tropicalis DIV13-Z087D0VS & $>1.000$ & - & $>1.000$ & - \\
\hline Candida tropicalis DIV13-Z087B0VS & 1.000 & 1.000 & 1.000 & 1.000 \\
\hline Mold & & & Griseofulvin & \\
\hline Aspergillus niger 1 & $>1.000$ & - & $>1.000$ & - \\
\hline Aspergillus niger 2 & $>1.000$ & - & $>1.000$ & - \\
\hline Aspergillus flavus & 1.000 & 1.000 & 0.250 & 1.000 \\
\hline
\end{tabular}

\section{DISCUSSION}

The phytochemical compositions of plants vary from one species to another and sometimes within the same species. These differences in composition confer important biological properties on plants. Twelve phytochemicals were detected in the aerial part of Satureja calamintha, namely: flavonoids, anthocyanins, total and gallic tannins; glycosides, saponosides, reducing compounds, holosides, alkaloids, coumarins, O-heterosides and C-glycosides. Leucoanthocyanins and quinones were not detected. Although catechic tannins and saponosides were present, they had minimal relative abundance.

A similar study carried out on Satureja calamintha (L.) Scheel. from Western Algeria showed the presence of saponosides, coumarins, total tannins and free flavonoids, but anthocyanins, leucoanthocyanins and reducing compounds were absent [11]. In another study on the same plant, the presence of flavonoids, total tannins, alkaloids, saponosides and quinones was reported [12]. These observed differences in chemical composition may be linked to variations in climatic and geographical conditions.

The extract yield from steam distillation was comparable to that reported in a previous study [13]. In contrast, a higher yield was obtained from the same species from Morocco [14]. Different extraction yields varying from 1.27 to $2.52 \%$ have been reported on the same plant grown in different parts of Algeria [12,15]. The three most abundant compounds identified in the EOs were 1-menthone, neo-menthol and pulegone.

The chemical compositions of oils extracted from Satureja calamintha differed from one region to another. In Algeria, studies on oils of this plant species collected from two different sites demonstrated the presence of twenty phytochemical components [15]. The sample from the first site was characterized by the predominance of piperitone oxide, cyclohexanone 2- (methylethylidene), and menthone, whereas the major compounds in the oils from the second site were menthone, piperitone oxide, pulegone, and cyclohexanone 2- (1-ethylthylidene). Studies carried out on oils from Satureja calamintha (L.) Scheel. from Belgium showed that the major compounds were pulegone, piperitenone oxide, and menthone [16]. In a study on the same plant from Italy, the dominant constituents were pulegone, piperitenone oxide, piperitone oxide, and piperitenone [13]. These differences in composition are due seasonal and environmental factors such as soil type, geographic location, harvest period and extraction method [17].

In the present study, the essential oils (EOs) from Satureja calamintha exhibited potent antibacterial activities. Gram-positive bacteria were more sensitive to the EOs than Gramnegative bacteria. These differences in susceptibilities indicate a possible effect of the 
EOs on the plasma membrane, since the walls of Gram-negative bacteria may be less permeable to antimicrobial agents. The outer layer of polysaccharides, proteins and lipids acts as a barrier to the entry of different chemical agents [18].

These results are in agreement with those obtained from previous studies [19]. However, they are better, when compared to the results obtained by Bensouici et al, [20] who reported inhibition zones ranging from 14 to $25 \mathrm{~mm}$ against Escherichia coli, Pseudomonas aeroginosa, Staphylococcus aureus and Klebsiella pneumoniae. The inhibition zones obtained in the present study are smaller than those reported by Gormez et al, [21]. The antifungal activities are also in agreement with previous reports $[13,19]$, but they differ from those obtained by Kerbouche et al, [19] who reported inhibition zone of $11.33 \mathrm{~mm}$ against Candida albicans; and also from values reported by Abdoune [22] who reported inhibition zone of $47 \mathrm{~mm}$ against the same fungal strain. The antibacterial and antifungal activities of the EOs may be linked to their richness in I-menthone, neo-menthol and pulegone. However, Monforte et al, [23] had earlier attributed the potent antimicrobial activities to carvone content. Some authors have suggested that minor components of the EOs may have some synergistic effects [24].

\section{CONCLUSION}

The phytochemical profile of aerial parts of Satureja calamintha (L.) Scheel. shows that the plant is rich in diverse secondary metabolites, which confer on it several biological properties. The essential oils demonstrated potent antimicrobial activities against different pathogenic strains of bacteria and fungi. These findings suggest that essential oils of the plant could be used as potential natural antimicrobial agents in pharmaceutical processes.

\section{DECLARATIONS}

\section{Conflict of Interest}

No conflict of interest associated with this work.

\section{Contribution of Authors}

The authors declare that this work was done by the authors named in this article and all liabilities pertaining to claims relating to the content of this article will be borne by them.

\section{REFERENCES}

1. Hennequin C. Épidemiologie des mycoses invasives. L'expérience d'un centre hospitalo-universitaire parisien. Rev Med Interne 1996; 17:754-760.

2. Diao WR, Hu QP, Feng SS, Li WQ, Xu JG. Chemical composition and antibacterial activity of the essential oils from green huajiao (Zanthoxylum schinifolium) against selected foodborne pathogens. J Agric Food Chem 2013; 61: 6044-6049.

3. Burt S. Essential oils: their antibacterial properties and potential applications in foods: a review. Inter $J$ Food Microbiol 2004; 94: 223-253.

4. Jassim $S A A$, Limoges RG. Natural solution to antibiotic resistance: bacteriophages 'The Living Drugs'. World J Microbiol Biotechnol 2014; 30: 2153-2170.

5. Lahlou M. Essential oils and fragrance compounds: bioactivity and mechanisms of action. Flavour fragr $J$ 2004; 19(2): 159-165.

6. Harborne JB. Phytochemical methods, London Chapman and Hall, Ltd, 1973: 49-88.

7. Boudjema K, Fazouane-Naimi F, Hellal A. Isolation, identification of yeast strains producing bioethanol and improvement of bioethanol production on cheese whey, Turk J Biochem 2016; 41(1): 157-166.

8. Bauer AW, Kirby WMM, Sherris JCT, Turck M. Antibiotic susceptibility testing by a standardized single disk method. Am J Clin Pathol 1966; 45: 493-496.

9. Adjou ES, Kouton $S$, Dahouenon-Ahoussi E, Sohounhloue CK, Soumanou MM. Antifungal activity of Ocimum canum essential oil against toxinogenic fungi isolated from peanut seeds in post-harvest in Benin. Int Res J Biological Sci 2012; 1(7): 20-26.

10. Erkmen $O$ and Ozcan M. Antimicrobial effects of essential oils on growth of bacteria, yeasts and molds. $J$ Essent Oil Bear PI 2004; 7(3): 279-287.

11. Bougandoura $N$, Bendimerad $N$. Evaluation of the antioxidant activity of aqueous and methanolic of Satureja calamintha ssp. Nepeta (L.) Briq. Nature \& Technolology 2003; 9: 14-19.

12. Benkhedimallah R, Kismoun S. Phytochemical and biological studies of Satureja calamintha. Master degree, University of Constantine 1, Algeria, 2014; $p 88$.

13. Panizzi L, Flamini G, Cioni PL, Morelli I. Composition and antimicrobial properties of essential oils of four Mediterranean Lamiaceae. J Ethnopharmacol 1993; 39(3): 167-170.

14. Satrani B, Ghanmi $M$, Farah A, Aafi A, Fougrach $H$, Bourkhiss $B$, Talbi M. Composition chimique et activité antimicrobienne de l'huile essentielle de Cladanthus mixtus. Bull Soc Pharm Bord 2007; 146: 85-96.

15. Labiod $R$. Valorization of essential oils and extracts of Satureja calamintha nepeta: antibacterial antioxidant and antifungal activities. PhD Thesis. University of Badji Mokhtar, Algeria, 2016; $p 115$

16. De Pooter HL, Goetghebeur P, Schamp N. Variability in composition of the essential oil of Calamintha nepeta. Phytochem 1987; 26(12): 3355-3356.

Trop J Pharm Res, May 2018; 17(5): 863 
17. Gende LB, Mendiara S, Fernández NJ, Van Baren $C$, Di Leo Lira A, Bandoni A, Eguaras M. Essentials oils of some Mentha spp. and their relation with antimicrobial activity against Paenibacillus larvae, the causative agent of American foulbrood in honey bees, by using the bioautography technique. Bull Insectol 2014; 67(1): 1320.

18. Cao G, Sofic E, Prior RL. Antioxidant and prooxidant behavior of flavonoids: structure-activity relationships. Free Radic Biol Med 1997; 22(5): 749-760.

19. Kerbouche L, Hazzit M, Baaliouamer A. Essential Oil of Satureja calamintha subsp. nepeta (L.) Briq. from Algeria: Analysis, Antimicrobial and Antioxidant Activities. Journal Biologically Active Products from Nature 2013; 3(4): 266-272.

20. Bensouici C, Benmerache A, Chibani $S$,Kabouche A, Abuhamdah S, Semra Z, Kabouche Z. Antibacterial activity and chemical composition of the essential oil of
Satureja calamintha ssp. sylvatica from Jijel, Algeria. Pharm Lett 2013; 5(2): 224-227.

21. Gormez A, Bozari S, Yanmis D, Gulluce M, Fikrettin Sahin F, Agar G. Chemical composition and antibacterial activity of essential oils of two Species of Lamiaceae against phytopathogenic bacteria. Pol J Microbiol 2015; 64(2): 121-127.

22. Abdoune MN. Preventive effect of some essential oils against growth and biofilm formation of some oral pathogens. Magister degree, University of Tlemcen, Algeria, 2013; $p 93$.

23. Monforte MT, Tzakou O, Nostro A, Zimbalatti V, Galati EM. Chemical composition and biological activities of Calamintha officinalis Moench essential oil. J Med Food 2011; 14: 297-303.

24. Wang $W, W u$ N, Zu YG, Fu YJ. Antioxidative activity of Rosmarinus officinalis $L$. essential oil compared to its main components. Food chem 2008; 108(3): 1019-1022. 